\title{
13
}

\section{Erratum to: Engaging with European Politics Through Twitter and Facebook: Participation Beyond the National?}

(C) The Author(s) 2017

M. Barisione, A. Michailidou (eds.), Social Media and European Politics, Palgrave Studies in European Political Sociology,

DOI 10.1057/978-1-137-59890-5_13

The Publisher regrets that the affiliation of Hans-Jörg Trenz in Chapter 3 was incomplete. It should read "Department of Media, Cognition and Communication, University of Copenhagen, Copenhagen, Denmark and ARENA Centre for European Studies, University of Oslo, Oslo, Norway."

The updated original online version for this chapter can be found at DOI 10.1057/978-1-137-59890-5_3

(C) The Author(s) 2017

E1

M. Barisione, A. Michailidou (eds.), Social Media and European

Politics, Palgrave Studies in European Political Sociology,

DOI 10.1057/978-1-137-59890-5_13 